\title{
Correction to: Primed for Success: The Story of Scientific Design Company
}

\section{Correction to:}

P. H. Spitz, Primed for Success: The Story of Scientific

Design Company, https://doi.org/10.1007/978-3-030-12314-7

The original version of the book was revised. The corrections which were inadvertently omitted in the original version have now been included. The erratum book has been updated with the changes. 